\title{
THE EUROPEAN WELFARE STATE REGIMES: QUESTIONING THE TYPOLOGY DURING THE CRISIS
}

\author{
Kosta JOSIFIDIS ${ }^{\mathrm{a}}$, John B. HALL ${ }^{\mathrm{b}}$, Novica SUPIC ${ }^{c}$, Emilija BEKER PUCAR ${ }^{\mathrm{d}}$ \\ ${ }^{\mathrm{a}, \mathrm{c}, \mathrm{d}}$ The Faculty of Economics Subotica, University of Novi Sad, Serbia \\ ${ }^{\mathrm{b}}$ The Department of Economics, Portland State University, USA
}

Received 05 February 2014; accepted 30 November 2014

\begin{abstract}
This paper examines the nature of changes within the EU-15 welfare states affected by the 2008 crisis. We try to answer the question of whether the differences that exist among different welfare state regimes, according to prevailing welfare state typologies, lead to different responses to the consequences of the crisis. Welfare state regimes are the result of different institutional perceptions of social risks hence it is realistic to expect specific responses to the effects of crisis among different welfare state regimes, and similar responses among the countries that belong to the same welfare state regimes. In order to recognize convergent vs. divergent processes, we perform a comparative analysis of the dynamics of the key welfare state determinants of the EU-15 countries, grouping according to welfare state regimes, in the pre-crisis and crisis periods. The results indicate that institutional rigidity and inherent inertia has remained a key factor of convergent welfare state processes in countries that belong to the Social Democratic and Corporatist welfare state regimes. Deviations from such a course are the most evident in the Mediterranean welfare state regimes, especially in Greece and Portugal where austerity measures have been formulated under the strong influence of the Troika.
\end{abstract}

Keywords: welfare state, economic crisis, the European Union, institutional changes, pension system, unemployment benefit system.

JEL Classification: D63, E24, H53, H55.

\section{Introduction}

The welfare state in the EU-15, due to inherent inertia and institutional rigidity, in the early years of the crisis had not shown significant signs of slowdown and decrease. However, the intensity of the recession, as well as the instigated financial, economic and fiscal adjustments to crisis circumstances, certainly had an effect on the welfare state. Therefore, the question is not whether the crisis will spill over into the welfare state, but rather how will the welfare state

Corresponding author Novica Supic

E-mail:novicasupic@yahoo.com 
reform in the newly emerging situation? Can we expect convergent or divergent responses between countries in this regard? Are cyclical changes sufficient or are structural changes in social policy also inevitable? To what extent can our existing theoretical frameworks of the welfare state typologies, developed for many years, be useful in understanding, and projecting, the future of the welfare state in the EU-15?

In order to contribute to the ongoing discussion of this topic, from a methodological point of view, the paper is divided into five sections. In the first part of the paper, we give a short literature survey on reactions of the EU-15 welfare state to the 2008 crisis. In the second part, we explain the selected methodology framework taking into account the main aim of the research as well as available data. In the third part, we analyze the impact and consequences of the crisis on absolute, as well as relative, position of the EU-15 welfare states, grouped according to the welfare state regimes. In the fourth part, we discuss the arguments, based on the obtained empirical results, in favour of potential welfare state reforms, firstly, in general, and secondly, focusing on the key welfare state programs - the pensions system and the unemployment benefit system. The final part of the paper summarizes the main findings and messages of the paper.

\section{Literature survey}

There are a number of papers that discuss the influence of the previous crises, and project the effects of the current crisis on the European welfare states in the institutional context. The findings contained in several papers were particularly influential for our research (Hemerijck et al. 2009; Castles 2010; Ferreiro, Gómez 2014; Hartmann-Hirsch 2010; Josifidis et al. 2010, 2014; Palier 2010; Stiller 2010; Adema et al. 2011; Chung, Thewissen 2011; Chung, Van Oorschot 2011; Sacchi et al. 2011; Starke et al. 2011, 2013; Theodoropoulou, Watt 2011; Vis et al. 2011; Yerkes, van der Veen 2011; Clasen et al. 2012; De Beer 2012; Blot et al. 2014; Hermann 2014; Peinado, Serrano 2014; Verbič, Spruk 2014). The authors listed above do not share unique opinion about the need, and type, of responses of the welfare state to the crisis in the context of long versus short term reforms, or convergent versus divergent reactions.

Using Greece as an example, Matsaganis (2011) showed that on one hand, the welfare state itself has contributed in a far from trivial way to the fiscal crisis of the state, but on the other hand, the welfare state can help cope with the consequences of the crisis. Enhancing its capacity to do so, however, will require considerable welfare state reconfiguration. Based on a review of national responses to the current crisis in 11 EU member states, Hermann (2014) argues that structural adjustments in the welfare state amount to a convergence of national economic and social models along the lines of neoliberal policy prescriptions. This phenomenon is ignored by Varieties of Capitalism scholars who assume that countries tend to respond differently to common challenges such as globalization and economic crises. Vis et al. (2011), focusing on selected advanced democracies (the UK, US, Germany, The Netherlands, Denmark, and Sweden), found that these countries face similar welfare state problems, and that their response to these problems is rather similar as well.

However, Starke et al. (2011), analyzing the reactions of four EU welfare states to three global crisis situations, including the 2008 financial crisis, conclude that crisis reactions were 
surprisingly diverse, which could be explained by partisan composition of government and the size of the existing welfare state. Similarly, Clasen et al. (2012), studying responses to the crisis in six EU member states, found that in the first phase of the crisis, all countries expanded their labour market policy efforts. As the crisis deepened, there was a clear bifurcation between those states that stepped up structural reforms intended to reduce labour market segmentation and those that turned to a more aggressive agenda of retrenchment. De Beer (2012), investigating the impact of the crisis on earnings and income distribution in five EU countries, found that the vehemence with which a crisis affects a country is linked to its labour market regulation. There is not, however, a one to one translation of difference in labour market adjustment into real incomes and income inequality, because such translation depends on policy measures taken during the crisis.

Generally, the contribution of our research to the existing literature could be recognized as an attempt to explain the consequences of the deepening internal gap between economic foundation and political dependence of the welfare state in the period of the crisis on the examples of the EU-15 countries. In particular, we are focused on the question of whether the institutional differences among the EU-15 welfare state regimes, which are used in welfare state typologies, resulted in the different approaches to welfare state reforms during the crisis. We expect that this paper will contribute to discussions about the validity of the welfare state typology framework in the period of the crisis, and induce additional research, particularly the analyses that address the issues of the reform of particular welfare state programs.

\section{Methodological framework and data sources}

The initial methodological issue in the analysis of the degree of convergence or divergence in the manifestations of the welfare state in response to economic shocks is the classification of countries according to welfare state regimes. The assumption is that similar institutional solutions, recognizable within the same regime, result in similar responses in crisis situations. Starting with the leading approaches in the classification of welfare regimes (Esping-Andersen 1990, 1996; Ferrera 1996; Bonoli 1997), and according to the aim of our research, we chose the division of the EU-15 into four regimes of the welfare state: (i) the Liberal welfare stare regime - LWR; (ii) the Social Democratic welfare stare regime - SDWR; (iii) the Corporatist welfare stare regime - CWR; and (iv) the Mediterranean welfare stare regime - MWR.

The intensity and dynamics of the Great Recession of 2008 had impacts across the financial, economic and fiscal sectors, and lead to the crisis of the welfare state. On the one hand, the hypothesis on the crisis of the welfare state is founded on the reduction of the basis for redistribution, due to the slowdown in economic growth and increasing the number of users of welfare state programs. On the other hand, there is the problem of high institutional rigidity of the welfare state, which results in slow response to economic shocks.

In order to test the hypothesis on the crisis of the welfare state based on the previously described causality, indicators which have been monitored in the paper are the GDP, unemployment and social public expenditure in pre-crisis and crisis years. The variations of the GDP change the size of the real basis for redistribution which, in the long term, has an influence on the generosity of social expenditure. Similarly, the demand for the programs of 
the welfare state is directly connected, in the short and long term, with the movement of the number of unemployed persons, which also influences the proportions of social expenditure. The adjustments of the welfare state to the circumstances of a narrowed redistribution base, along with a growing demand for social expenditure, require changes to the mechanisms of the welfare state programs. Changes include both quantitative changes, and qualitative changes such as institutional reform of the welfare state.

For each indicator, we have determined: (i) changes in the crisis years, from 2008 until 2012, in relation to the pivotal 2007; (ii) the trend in the pre-crisis and crisis periods; and (iii) changes, caused by the crisis, in the relative position of the countries as well as the welfare state regimes in the EU-15 group. Such an approach gives us an opportunity to analyse and discuss the impact of the crisis on the EU-15 welfare states and regimes in absolute, as well as relative, terms. Changes in relation to the initial, non-crisis situation are calculated by indexes, where 2007 is taken as a basis. Trend calculation is based on the Average Annual Rate of Change - AARC methodology. The AARC procedure implies the selection of two temporal points, the starting and end point, between which the trend of the time series is determined, based on the formula derived from the calculated net present value:

$$
r=\Delta t \sqrt{\frac{x_{t+T}}{x_{t}}}-1
$$

Symbols respectively indicate: $x_{t}$ - the starting year in the observed period, $x_{t+T}-$ the end year of the observed period, $t$ - time, $\Delta t$ - change in the observed period.

To test the hypothesis that countries that belong to the same welfare state regimes have similar reactions to economic shocks, it is necessary to adopt an appropriate definition of convergence. To this end, we chose the concept of relative sigma convergence. According to this approach, convergence occurs when either the dispersion of the observed value, as measured by the coefficient of variation, decreases over time, or when the condition is met:

$$
C V_{t+T}<C V_{t}
$$

where $C V_{t+T}$ is the coefficient of variation in the period $t+T$ and $C V_{t}$ is the coefficient of variation in time $t$. In this way it is possible to determine how the values of the selected indicator change, in the observed country, in relation to the average values of the given indicator in the group of countries that constitute a particular regime of the welfare state.

In the last step of the research, after gaining general insight into the reflection of the crisis on the GDP, unemployment and social public expenditure, as well as determining the (non) existence of convergence between countries and welfare state regimes, we shall focus our attention on highlighting the changes in the two segments of the welfare state. In our opinion, this reflects the necessity and the direction of changes in European welfare states in the next decade: (i) the pension system; and (ii) the unemployment benefit system. 


\section{The great recession and the crisis of the welfare state}

\subsection{Production - the basis for redistribution}

Manifestations of the Great recession of 2008 were largely the same in all the EU countries, expressed through the decline in values of key macroeconomic indicators. However, the intensity of the crisis was not uniform, which is understandable given the specific features of the economic structure, as well as public finances, among countries. Consequently, the reactions to the crisis, through the economic policy, were varied, ranging from harsh austerity measures, required by international financial organizations in countries most affected by the crisis, to the use of limited bailout packages for the banking sector in countries where the crisis has not reached full momentum. Particularly affected were the countries where, parallel with anti-cyclical measures, structural reforms have been implemented, with the support and monitoring of the Troika.

Table 1 contains the data providing a generalized view of the level and dynamics of GDP of the EU-15 countries, grouped according to welfare state regimes, before and during the crisis. In the pre-crisis period, from 1995 to 2007, the trend of GDP growth had been noticeable in the all countries (column 7). Growth trends were strongest in LWR countries,

Table 1. The impact of the crisis on GDP (PPS) in the EU-15

\begin{tabular}{|c|c|c|c|c|c|c|c|c|c|c|}
\hline \multirow{3}{*}{$\begin{array}{l}\text { Country/ } \\
\text { regimes }\end{array}$} & \multicolumn{8}{|c|}{$\begin{array}{c}\text { Absolute position } \\
\text { (GDP - level changes and trend) }\end{array}$} & \multicolumn{2}{|c|}{$\begin{array}{l}\text { Relative position } \\
\text { (share in the } \\
\text { EU-15 GDP) }\end{array}$} \\
\hline & 2007 & 2008 & 2009 & 2010 & 2011 & 2012 & $\begin{array}{c}\% \\
\text { AARC } \\
1995-2007\end{array}$ & $\begin{array}{c}\% \\
\text { AARC } \\
2007-2012\end{array}$ & 2007 & 2012 \\
\hline & (1) & (2) & (3) & (4) & (5) & (6) & (7) & (8) & (9) & (10) \\
\hline Germany & 100 & 100.4 & 93.0 & 99.9 & 104.5 & 107.6 & 3.7 & 1.5 & 21.7 & 22.8 \\
\hline France & 100 & 99.8 & 96.1 & 100.1 & 103.3 & 105.7 & 4.5 & 1.1 & 15.7 & 16.2 \\
\hline Belgium & 100 & 100.8 & 97.2 & 103.3 & 106.7 & 108.9 & 4.0 & 1.7 & 2.8 & 3.0 \\
\hline Austria & 100 & 101.1 & 96.0 & 101.8 & 106.4 & 109.8 & 4.2 & 1.9 & 2.4 & 2.5 \\
\hline CWR & 100 & 100.5 & 95.6 & 101.3 & 105.2 & 108 & 4.1 & 1.6 & 42.9 & 44.9 \\
\hline Netherlands & 100 & 101.9 & 94.7 & 98.5 & 101.4 & 102.7 & 5.7 & 0.5 & 4.9 & 5.0 \\
\hline Sweden & 100 & 99.9 & 91.8 & 99.2 & 105.4 & 108.8 & 4.8 & 1.7 & 2.6 & 2.8 \\
\hline Denmark & 100 & 102.3 & 95.7 & 103.7 & 104.8 & 106.8 & 4.3 & 1.3 & 1.5 & 1.6 \\
\hline Finland & 100 & 101.9 & 92.5 & 95.9 & 100.0 & 102.1 & 5.6 & 0.4 & 1.4 & 1.4 \\
\hline SDWR & 100 & 101.5 & 93.7 & 99.3 & 102.9 & 105.1 & 5.1 & 1.0 & 10.5 & 10.7 \\
\hline Italy & 100 & 101.1 & 95.0 & 96.8 & 98.6 & 98.5 & 3.6 & -0.3 & 14.1 & 13.6 \\
\hline Spain & 100 & 100.6 & 94.7 & 95.4 & 97.0 & 97.9 & 6.9 & -0.4 & 10.7 & 10.2 \\
\hline Greece & 100 & 103.1 & 98.9 & 95.1 & 89.1 & 85.3 & 5.7 & -3.1 & 2.3 & 1.9 \\
\hline Portugal & 100 & 99.4 & 96.1 & 100.4 & 99.6 & 98.7 & 5.2 & -0.3 & 1.9 & 1.8 \\
\hline MWR & 100 & 101.0 & 96.2 & 96.9 & 96.1 & 95.1 & 5.3 & $\begin{array}{l}-1.0 \\
\end{array}$ & 29 & 27.5 \\
\hline UK & 100 & 97.4 & 90.6 & 95.3 & 96.6 & 99.1 & 5.2 & -0.2 & 16.2 & 15.7 \\
\hline Ireland & 100 & 91.9 & 85.1 & 88.4 & 91.4 & 94.4 & 9.3 & -1.2 & 1.5 & 1.3 \\
\hline LWR & 100 & 94.7 & $\begin{array}{l}87.8 \\
\end{array}$ & 91.8 & 94.0 & 96.7 & 7.3 & -0.7 & 17.7 & 17 \\
\hline
\end{tabular}

Note: Luxembourg is not included in the analysis.

Source: The authors' estimation based on AMECO 2013 data. 
on average $7.3 \%$ annually (a particularly illustrative example is Ireland which, in 2007 , had almost three times the GDP in relation to 1995), while in the other welfare state regimes the trend of GDP growth was almost even, approximately $5 \%$ per year.

The crisis was strongly reflected in the GDP of the EU-15 countries. This is illustrated by the fact that in 2009 none of the countries had achieved the value of production from 2007 (column 3). In relation to the welfare state regimes, the crisis hit MWR and LWR the hardest, in which all countries marked a negative trend compared to the pre-crisis situation. Particularly vulnerable are the economies of Greece and Ireland, which have, on average, declined annually by more than 3 and 1 percentage point, respectively, compared to the base year 2007 (column 8). In contrast, other countries and welfare states regimes, after three years from the outbreak of crisis, have brought their economies back to the initial state. When looking at GDP growth, however, these countries are several times below the values achieved in the pre-crisis period.

It is useful to note that the crisis led to a change in the relative position of particular countries in the creation of GDP EU-15 (columns 9 and 10). Decrease in the share of GDP EU-15 in 2012, compared to 2007, is most obvious in MWR countries ( -1.5 percentage point - pp) and LWR countries $(-0.7 \mathrm{pp})$, while the share of CWR and SDWR countries increased $(+2 \mathrm{pp}$ and $+0.2 \mathrm{pp}$, respectively). This indicates a redistribution of economic power from the periphery towards the centre and the north of the EU-15.

\subsection{Unemployment - interweaving of economy and the welfare state}

The pressure of unemployment on the labour market and the welfare state is not synchronized. The consequences of unemployment spill over to the welfare state more slowly than is the case with the labour market. The institutions of the welfare state are characterized by a higher degree of rigidity in relation to the institutions of the labour market, which is why social problems, in the short term, may be disguised through the inertial application of existing generous welfare state programs. Consequently, the rise of unemployment does not have to be directly manifested through the rise of poverty or social exclusion, but the decline in economic activity in the long term, and persistently high unemployment rates, bring about future exhaustion of the welfare state and the explosion of social problems.

For a number of years, economies and the welfare states of the EU-15 countries have been faced with the problem of unemployment, especially regarding socially vulnerable groups: young people, women and immigrants. However, in the pre-crisis period, in most countries a tendency of the reduction of unemployment had been present. Thus, from the Table 2 it is evident that in 2007, compared to 1995, the number of the unemployed persons was higher in only 4 countries: Greece, Germany, Austria and Portugal (column 7). In terms of the welfare state regimes, the trend of a slight rise in the number of unemployed persons in the pre-crisis period had been recorded in CWR, along with the fact that the average values of MWR hide within them a relatively good position of Italy and Spain, which compensated for the negative trends in the labour markets of Portugal and Greece.

The crisis of 2008 has dramatically changed the dynamics of unemployment in the EU-15. In comparison to 2007, the trend of a decrease in the number of unemployed persons has only been present in Germany, while negative trends have been observed in all other countries. 
Table 2. The impact of the crisis on unemployment in the EU-15

\begin{tabular}{|c|c|c|c|c|c|c|c|c|c|c|}
\hline \multirow{3}{*}{$\begin{array}{l}\text { Country/ } \\
\text { regimes }\end{array}$} & \multicolumn{8}{|c|}{$\begin{array}{c}\text { Absolute position } \\
\text { (Total unemployment - level changes and trend) }\end{array}$} & \multicolumn{2}{|c|}{$\begin{array}{c}\text { Relative position } \\
\text { (compared } \\
\text { with EU-15 } \\
\text { unemployment } \\
\text { rate) } \\
\end{array}$} \\
\hline & 2007 & 2008 & 2009 & 2010 & 2011 & 2012 & $\begin{array}{l}\text { \% AARC } \\
1995- \\
2007 \\
\end{array}$ & $\begin{array}{c}\text { AARC } \\
2007- \\
2012 \\
\end{array}$ & 2007 & 2012 \\
\hline & $(1)$ & (2) & (3) & (4) & (5) & (6) & $(7)$ & $(8)$ & (9) & (10) \\
\hline Germany & 100 & 87.1 & 89.6 & 81.8 & 69.5 & 64.3 & 0.9 & -8.4 & 22.5 & -48.1 \\
\hline France & 100 & 93.6 & 115.6 & 118.7 & 117.6 & 126.2 & -1.2 & 4.8 & 12.7 & -7.5 \\
\hline Belgium & 100 & 94.4 & 107.5 & 115.0 & 98.3 & 104.5 & -1.2 & 0.9 & 5.6 & -28.3 \\
\hline Austria & 100 & 87.4 & 110.1 & 101.4 & 96.4 & 101.8 & 1.9 & 0.4 & -38.0 & -59.4 \\
\hline CWR & 100 & 90.6 & 105.7 & 104.2 & 95.5 & 99.2 & 0.1 & -0.6 & 0.7 & -35.8 \\
\hline Netherlands & 100 & 87.5 & 106.8 & 127.5 & 127.1 & 153.4 & -4.4 & 8.9 & -49.3 & -50.0 \\
\hline Sweden & 100 & 102.4 & 137.2 & 142.9 & 131.1 & 135.5 & -2.2 & 6.3 & -14.1 & -24.5 \\
\hline Denmark & 100 & 91.5 & 159.8 & 197.0 & 199.8 & 197.7 & -4.3 & 14.6 & -46.5 & -29.2 \\
\hline Finland & 100 & 93.8 & 120.5 & 122.3 & 113.8 & 112.9 & -5.9 & 2.5 & -2.8 & -27.4 \\
\hline SDWR & 100 & 93.8 & 131.1 & 147.4 & 143.0 & 149.9 & -4.2 & 8.1 & -28.2 & -32.8 \\
\hline Italy & 100 & 112.3 & 129.1 & 139.6 & 140.0 & 182.6 & -4.5 & 12.8 & -14.1 & 0.9 \\
\hline Spain & 100 & 141.3 & 226.3 & 252.6 & 272.6 & 314.6 & -4.7 & 25.8 & 16.9 & 135.8 \\
\hline Greece & 100 & 92.9 & 115.8 & 154.5 & 215.5 & 296.9 & 0.4 & 24.3 & 16.9 & 129.2 \\
\hline Portugal & 100 & 95.6 & 118.4 & 133.9 & 143.7 & 175.0 & 3.2 & 11.8 & 25.4 & 50.0 \\
\hline MWR & 100 & 110.5 & 147.4 & 170.1 & 192.9 & 242.3 & -1.4 & 18.7 & 11.3 & 79.0 \\
\hline UK & 100 & 108.0 & 145.6 & 150.4 & 156.1 & 154.9 & -3.1 & 9.1 & -25.4 & -25.5 \\
\hline Ireland & 100 & 139.0 & 255.2 & 288.6 & 301.9 & 301 & -4.3 & 24.7 & -33.8 & 38.7 \\
\hline LWR & 100 & 123.5 & 200.4 & 219.5 & 229.0 & 227.9 & -3.7 & 16.9 & -29.6 & 6.6 \\
\hline
\end{tabular}

Note: Luxembourg is not included in the analysis.

Source: The authors' estimation based on AMECO 2013 data.

The largest increase in unemployment was recorded in LWR and MWR. Compared to the pre-crisis situation in 2007, the number of unemployed persons grew during the crisis by $18.7 \%$ on average and $16.9 \%$ annually in LWR and MWR countries (column 8). Particularly affected were Ireland, Spain and Greece, countries where the number of unemployed persons in 2012 was almost three times higher than in 2007 (column 6).

The analysis of relative position of the countries and welfare regimes in the EU-15 group has shown that CWR countries improved their position during the crisis - from the countries with unemployment rate above the EU-15 average to the countries with unemployment rate below the EU-15 average. The worst situation has been recorded in the MWR countries. In 2012, the unemployment rate in those countries was on average $79 \%$ higher compared with the EU-15 average. The situation is even worse keeping in mind the fact that the unemployment rate in the EU-15, before the crisis, was the highest in the MWR countries with the exception of Italy. Concerning SDWR and LWR, the SDWR countries and the UK have kept, more or less, the same position - better than the EU-15 average (columns 9 and 10). 
$584 \mathrm{~K}$. Josifidis et al. The European welfare state regimes: questioning the typology during the crisis

\subsection{Social public expenditure - manifestations of the welfare state}

During the crisis, the EU-15 countries were faced with similar types, but different intensities, of social problems. Using the logic of the convergence theory, it is possible to define a hypothesis that assumes countries that belong to the same welfare state regimes adjust their welfare state in a similar, convergent, way to the new conditions caused by the economic crisis. Similarly, the countries that belong to the different welfare state regimes adjust the welfare state in a different, divergent, way to the crisis. Accepting such a hypothesis implies the existence of a strong link between institutional design of the welfare state and economic shocks, while its rejection means that: (i) all welfare state regimes have a common basis that is relatively independent of economic shocks; and/or (ii) there is no political willingness to adjust the existing social programs in accordance with the changed economic situation.

Table 3 shows the changes in social public expenditure in the EU-15 countries in the precrisis and crisis period. We observe two indicators: real social public expenditure and SPE/ GDP ratio. Countries are grouped according to the welfare state regimes. Within individual regimes, countries are ranked based on the size of the economy (in terms of the \% share of GDP in EU-28) so that the specificity of the definition and implementation of anti-crisis measures in large and small countries could be indicated in the discussion of results. Based on the data from columns 9 and 10, we can conclude that the volume of social expenditure, in relative terms, is not directly related to the size of the economy. Thus, in 2012, France had the most generous social expenditure as measured by the SPE/GDP ratio ( $18.8 \%$ above the EU-15 average) whereas Ireland and Greece had the lowest (14.4\% and $14.3 \%$ below the EU-15 average).

In the pre-crisis period, the trend in social spending, as measured by the SPE/GDP ratio, had been negative in most of the welfare state regimes. On average, each year, the share of social expenditure in the GDP was lower by $0.14 \%$ in CWR, $1.21 \%$ in SDWR and $0.22 \%$ in LWR. The exceptions were MWR countries, in which allocation from the GDP towards social expenditure increased by an average of $1.58 \%$ annually. It is interesting to note that the SPE/ GDP ratio grew in the countries with the lowest share of the GDP directed towards social expenditure, while it shrank in countries where social expenditure had the largest share of the GDP. An exception in this regard is France, where the SPE/GDP ratio increased during the pre-crisis period, despite the high initial SPE/GDP ratio (column 7).

The Great Recession of 2008 had a significant influence on the size of the economic resources absorbed by the welfare state. Data from column 8 shows that in all countries the share of social expenditure in the GDP had increased. The upward trend was most pronounced in LWR (4.9\%), then MWR (2.6\%) and SDWR (2.4\%), while the allocations for social expenditure increased the least in CWR (1.7\%). Compared to the pre-crisis period, we can notice that MWR countries remained on the path of high social expenditure, while other countries changed their path from a reduction of, to the increase of, allocations for social spending. Does this mean that the crisis affected generosity of EU-15 welfare states in the sense that countries where social expenditure had decreased the most in the pre-crisis period became countries where social expenditure grown the most during the crisis period? 
Table 3. The impact of the crisis on social public expenditure in the EU-15

\begin{tabular}{|c|c|c|c|c|c|c|c|c|c|c|}
\hline \multirow{3}{*}{$\begin{array}{l}\text { Country/ } \\
\text { regimes }\end{array}$} & \multicolumn{8}{|c|}{$\begin{array}{c}\text { Absolute position } \\
\text { (Real social spending - level changes; SPE/GDP trend) }\end{array}$} & \multicolumn{2}{|c|}{$\begin{array}{c}\text { Relative position } \\
\text { (compared with } \\
\text { EU-15 SPE/ } \\
\text { GDP) }\end{array}$} \\
\hline & 2007 & 2008 & 2009 & 2010 & 2011 & 2012 & $\begin{array}{c}\% \\
\text { AARC } \\
1995- \\
2007\end{array}$ & $\begin{array}{c}\% \\
\text { AARC } \\
2007- \\
2012\end{array}$ & 2007 & 2012 \\
\hline & $(1)$ & (2) & (3) & (4) & (5) & (6) & (7) & $(8)$ & (9) & $(10)$ \\
\hline Germany & 100 & 100.0 & 105.0 & 106.0 & 104.0 & 104.0 & -0.50 & 0.9 & 5.1 & -2.7 \\
\hline France & 100 & 100.0 & 105.0 & 107.0 & 107.0 & 107.0 & 0.11 & 1.6 & 24.5 & 18.8 \\
\hline Belgium & 100 & 104.0 & 111.0 & 112.0 & 113.0 & 113.0 & -0.08 & 2.9 & 8.9 & 10.9 \\
\hline Austria & 100 & 102.0 & 107.0 & 109.0 & 107.0 & 107.0 & -0.08 & 1.5 & 10.0 & 4.8 \\
\hline CWR & 100 & 101.5 & 107.0 & 108.5 & 107.8 & 107.8 & -0.14 & 1.7 & 12.1 & 7.9 \\
\hline Netherlands & 100 & 100.0 & 106.0 & 109.0 & 110.0 & 110.0 & -0.98 & 2.8 & -11.4 & -10.0 \\
\hline Sweden & 100 & 100.0 & 105.0 & 106.0 & 105.0 & 108.0 & -1.31 & 0.6 & 14.5 & 4.4 \\
\hline Denmark & 100 & 101.0 & 107.0 & 110.0 & 109.0 & 110.0 & -0.74 & 2.9 & 10.8 & 12.9 \\
\hline Finland & 100 & 102.0 & 110.0 & 113.0 & 113.0 & 114.0 & -1.79 & 3.2 & 3.5 & 7.2 \\
\hline SDWR & 100 & 100.8 & 107.0 & 109.5 & 109.3 & 110.5 & -1.21 & 2.4 & 4.4 & 3.6 \\
\hline Italy & 100 & 102.0 & 106.0 & 106.0 & 104.0 & 103.0 & 1.87 & 2.6 & 3.6 & 4.1 \\
\hline Spain & 100 & 106.0 & 117.0 & 117.0 & 114.0 & 110.0 & -0.03 & 4.3 & -10.6 & -2.6 \\
\hline Greece & 100 & 103.0 & 109.0 & 100.0 & 92.0 & 83.0 & 1.76 & 1.4 & -9.6 & -14.3 \\
\hline Portugal & 100 & 101.0 & 110.0 & 111.0 & 105.0 & 97.0 & 2.73 & 1.9 & -4.8 & -7.4 \\
\hline MWR & 100 & 103.0 & 110.5 & 108.5 & 103.8 & 98.3 & 1.58 & 2.6 & -5.3 & -5.1 \\
\hline the UK & 100 & 104.0 & 111.0 & 112.0 & 111.0 & 109.0 & -0.63 & 3.2 & -14.7 & -11.7 \\
\hline Ireland & 100 & 107.0 & 120.0 & 118.0 & 114.0 & 111.0 & 0.19 & 6.7 & -29.8 & -14.4 \\
\hline LWR & 100 & 105.5 & 115.5 & 115.0 & 112.5 & 110.0 & -0.22 & 4.9 & -22.2 & -13.0 \\
\hline
\end{tabular}

Note: Luxembourg is not included in the analysis.

Source: The authors' estimation based on OECD 2013 data.

When interpreting data on the share of social expenditure in the GDP, it is necessary to take into account that in the conditions of a downturn in economic activity, the SPE/GDP ratio can increase for two reasons: (i) social expenditure remains constant or increases to meet the growing need for programs of the welfare state (for example, unemployment benefits); and (ii) due to the stagnation or slowdown of GDP growth. Therefore, in order to indicate the nature of change in social public expenditure, it is necessary to analyze, parallel with the SPE/GDP ratio, the changes in real social public expenditure.

The dynamics of real social public expenditure from 2007 to 2012 reveals a different picture regarding the intensity of changes in the generosity of the welfare state (columns 1-6). Although real social expenditure has increased in most countries, its growth is slower than the growth of the SPE/GDP ratio. In this context, particularly illustrative are the MWR countries in which, in 2012, real social public expenditure was lower than was the case in pre-crisis 2007. In other welfare state regimes, the growth of real social expenditure is steady 
at approximately $10 \%$ compared to 2007 . The explanation for the decline in real social expenditure in MWR countries should be observed, except in the more pronounced decrease of GDP compared to the EU-15 average, in the slashing of monetary social transfers as a result of applied austerity measures.

\section{Discussion}

\subsection{General observations}

Comparative analysis of the changes in GDP, unemployment and social public expenditure, caused by the Great Recession of 2008, prejudges inevitable adjustments of the existing welfare state regimes in the context of the mechanisms and institutions of the welfare state. Facts derived from such predictions are:

- The economic crisis reduces the scope for redistribution through the welfare state. GDP reduction in MWR and LWR countries on one hand, and the declining of the trend of its growth in SDWR and CWR on the other hand, point to a decreasing real basis for redistribution in the EU-15.

- The unemployment crisis spreads and deepens social problems. In all the EU-15 countries, except Germany, the crisis has been accompanied by an increase in the number of unemployed persons. A consequence is the intensification of the existing, and the emergence of new, social problems which creates additional pressure on social expenditure and generates a crisis of the welfare state in the conditions of decline of real funds for redistribution.

- The crisis in social expenditure threatens the generosity of the welfare state programs. Maintaining the current SPE/GDP ratio, and the stagnation or decline in real social public expenditure, present indicators of slow adjustment of the welfare state to economic shocks due to greater institutional rigidity of the welfare state in relation to the labour market and public finances. Experience of previous crises suggests that the status quo of social expenditure is not sustainable in conditions of permanently present high rates of unemployment and low GDP growth rates.

The need to reform the welfare state towards achieving greater efficiency in social expenditure is inevitable. In the short term, it is reasonable to expect adjustments in the context of higher input efficiency (better results in combating social problems with unmodified resources of the welfare state), while in the long term cuts in terms of output efficiency seem inevitable (to achieve existing results with decreased resources of the welfare state). CWR and SDWR countries lean towards the first scenario, whereas in LWR countries, the second scenario seems more certain. In MWR countries, the second scenario is actually taking place. Moreover, LWR and MWR, with exception of the UK, belong to group of PIIGS countries with the pessimistic perspective concerning further economic recovery and development in the EU-28. Thus, Brauers et al. (2012), using the MULTIMOORA method, showed that the PIIGS countries are classified at the bottom in economic terms of achieving the European Strategy for 2020. 
Taking into account the presented current economic and social context of the European welfare state, the question arises of whether the awareness on the need to reform the welfare state resulted in concrete actions, in the domain of the mechanisms, as well as the institutions of the welfare state. In addition, to what extent is institutional heritage an indicator for convergent or divergent adjustments? In an attempt to provide an answer to this question, we shall focus our attention on social expenditure as a key manifestation of the welfare state, endeavouring to more closely pinpoint the obvious changes and redirections.

The starting point in highlighting the response of the welfare state to the crisis was to test whether the effects of the economic crisis led to comparable, convergent changes in disbursements for social expenditure regarding the welfare state regimes.

According to Figure 1 it is evident that prior to 2007, there was a convergent dynamic of social spending in the most welfare state regimes. This situation remained unchanged until 2010, when the movement of social expenditure in MWR countries slowly began to take on divergent characteristics. One possible explanation is the decline in real social public expenditure in MWR countries due to the high pressure of austerity measures. The reduction in social public expenditure did not have the same intensity in the MWR group. Greece and Portugal, countries that have been most affected by the crisis, and are where the austerity measures imposed by the Troika, have reduced the welfare state more than the other countries, below the level that are expected according to the institutional foundation of their welfare state. In the other words, institutional legacy, lying in the dominant welfare state typologies, remains a factor of convergent dynamics in countries within the same welfare state regime, and an acceptable explanation of the divergence between countries belonging to different regimes. Deviations from such a course are noticeable in MWR countries such as Greece and Portugal where austerity measures have been formed under strong external influence.

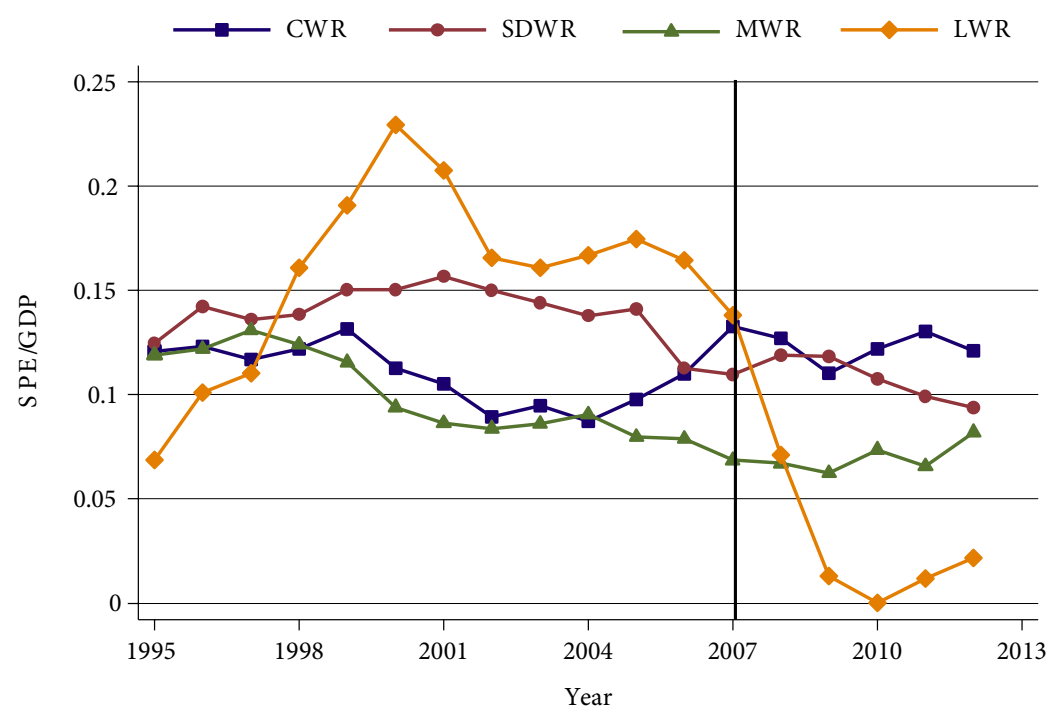

Fig. 1. Sigma convergence SPE/GDP in the EU-15 welfare state regimes, 1995-2012 Source: The authors' estimation based on OECD 2013 data. 
The analysis of sigma convergence of social expenditure offers a very general overview of trends in social expenditure during the crisis. In order to get a more complete picture, it is necessary to indicate the changes in key programs of the welfare state. The largest problems for welfare state regimes in the EU-15 are the most generous programs - the systems of pension and health care insurance that create increasing pressure on budgets and, as such, shall be the most difficult to sustain in the coming years.

The emergence of new social risks that need to be covered by the welfare state should be added to the existing problems. In other words, parallel with the efforts to increase the efficiency of existing social policies, new social policies for new social risks are also needed. New social risks and, consequently, new social policies provoked by the crisis, are primarily recognizable in the forms of: (i) active labour market policies that should enable workers to adapt quickly to changes in the economic structure; (ii) family policies which are expected to reduce the gap between family and work obligations; and (iii) education policies that are aimed at reducing youth unemployment in the labour market.

Keeping this in mind, the paper will be limited to the single largest component of social expenditure - the pension system and the component for which it is assumed that, in the future, will be the focus of economic and social policy regarding neutralizing economic shocks - the system of unemployment benefits.

\subsection{The first focus: the pension system}

Pension expenditures represent the largest single component of social public expenditure in all the EU-15 countries, with an average share in the GDP of 13\% in 2010 (Eurostat 2014). As we can see from the Table 4, in the period from 1995 to 2007, in most countries, pension share in the GDP had been reduced. In terms of the welfare state regimes, the decline was most pronounced in SDWR, on average over 10\%. The exceptions were the Mediterranean countries Italy, Greece and Portugal where spending on pensions increased by $30 \%$. In the crisis period, all countries had increased pension spending, as measured by the share of pensions in the GDP. In addition, countries that had the highest increase in pension expenditure in the pre-crisis period registered below average increases during the crisis. Projections through 2020 suggest that the trend of increasing social public expenditure on pensions shall continue into the future. However, there is no clear connection between the predicted dynamics of social expenditure on pension, and the classification of the EU-15 countries according to welfare state regimes.

When interpreting the results one should take into account that different values are obtained when analyzing absolute instead of relative indicators. The explanation for the more rapid growth of pension expenditures in MWR countries compared to the EU-15 average in the pre-crisis period should not be interpreted according to differences in generosity regarding pensions of a particular welfare state regime, but rather by factors that are more of an institutional - statistic than economic nature. In our opinion, it concerns the activity of three factors: (i) MWR countries are characterized by a lower absolute level of pensions compared to the EU-15 average, which resulted in the tendency of their rapid increase. This is particularly true in the pre-crisis period due to good economic results 
Table 4. The change of social public expenditure on pensions as \% of GDP, EU-15

\begin{tabular}{lclclc}
\hline \multicolumn{1}{c}{ Country } & $\begin{array}{c}\text { \% change } \\
1995-2007\end{array}$ & Country & $\begin{array}{c}\text { \% change } \\
2007-2009\end{array}$ & Country & $\begin{array}{c}\text { \% change } \\
2007-2020^{*}\end{array}$ \\
\hline Netherlands & -17.9 & Germany & 6.3 & Germany & 3.0 \\
\hline Ireland & -17.9 & Netherlands & 8.0 & Italy & 3.8 \\
\hline Sweden & -12.2 & Greece & 8.2 & Greece & 13.6 \\
\hline Denmark & -10.8 & France & 9.5 & France & 14.8 \\
\hline Spain & -10.4 & Denmark & 10.1 & Austria & 24.0 \\
\hline Finland & -6.0 & Italy & 10.5 & Portugal & 25.9 \\
\hline Belgium & -5.4 & Austria & 10.6 & UK & 31.2 \\
\hline Austria & -1.3 & Belgium & 13.6 & Spain & 31.3 \\
\hline UK & -0.5 & Sweden & 14.6 & Sweden & 33.8 \\
\hline Germany & 0.7 & Portugal & 14.9 & Belgium & 48.3 \\
\hline France & 4.3 & Spain & 15.0 & Netherlands & 56.3 \\
\hline Italy & 23.9 & UK & 16.0 & Finland & 69.5 \\
\hline Greece & 24.9 & Finland & & Denmark & 94.6 \\
\hline Portugal & 49.0 & Ireland & 20.4 & Ireland & 152.4 \\
\hline
\end{tabular}

\begin{tabular}{|l|}
\hline LWR \\
\hline MWR \\
\hline CWR \\
\hline SDWR \\
\hline
\end{tabular}

Note: The forecast value for 2020 is taken from OECD Pensions Outlook 2012. p. 210, Luxembourg is not included in the analysis.

Source: The authors' estimation based on OECD 2013 data.

and the absence of problems regarding financing of public expenditure; (ii) the level and rate of growth of the GDP in MWR was lower than the EU-15 average. Therefore, with the relatively unchanged or slightly rising pension expenditures, there has been a significant statistical effect of increase of pension share in the GDP. The correctness of this interpretation can be corroborated by the example of Ireland, which, in the period 1997-2007, was at the penultimate position according to the share of pensions in the GDP. With the advent of the crisis, and the decline in GDP, Ireland became the country that allocated the largest share of pensions relative to the GDP; (iii) CWR and SDWR countries have built, over time, a relatively stable and reliable system of financing public pensions that is less sensitive to economic fluctuations, as evidenced by smaller variations in pensions before and during the crisis than in MWR and LWR countries.

The rigidity of social public expenditure on pensions in conditions of the fiscal crisis enhanced the awareness of the need for institutional reforms of pension systems. Consequently, during the crisis, pension systems have been reformed in many countries. Institutional reforms are directed in two ways: (i) lowering of replacement rates; and (ii) extension of retirement age. The intensity of reforms is most pronounced in MWR countries where pension systems are facing the problem of sustainability even in relatively short periods of time, with a high risk of failure in old age poverty prevention. However, data from the fRDB - IZA database shows that a number of reforms of pension systems in the EU-15 countries during the crisis follow a pattern from the pre-crisis period. This suggests that the crisis was not actually the trigger of reforms, but it did affect their intensity (Armingeon 2013). 
The explanation of this situation, in addition to the institutional rigidity of the welfare state to economic shocks, should also be sought in the factors that determine the dynamics of social public expenditure on pensions. According to the Pench et al. (2012), in a predominant number of EU countries the dependent ratio (the ratio of the population aged 65 and over to the population aged 20 to 64 ) is the only factor that contributes to the growth of pension expenditures in the GDP. However, in most cases the coverage ratio, the employment effect, as well as the benefit ratio, gives a downward tone to the growing trend of pension expenditure. Viewed in an interrelated manner, the effect of an increase in the elderly population has a stronger influence on the dynamics of social public expenditure on pensions, in relation to the cumulative effect of other determinants that are traditionally regarded as guidelines for pension systems development (Coverage Ratio Contribution, Employment Effect Contribution, Benefit Ratio Contribution and Labour Intensity Contribution). As the growth of the dependent ratio is an independent variable in relation to economic shocks, and other variables analyzed are dependent variables, it follows that the primary motivation for reform should be found in factors whose dynamics are not caused by the crisis, noting that the intensity of the changes depends on the intensity of the crisis, as indicated by examples of MWR countries.

\subsection{The second focus: unemployment benefits}

Unemployment benefits have a relatively small share in the total social public expenditure of the EU-15 countries. On average, the EU-15 countries allocate for these purposes less than $2 \%$ of GDP, including both components: (i) unemployment insurance; and (ii) unemployment assistance; and both forms of benefits: (i) cash benefits; and (ii) benefits in kind, which is much lower compared to the costs of the pension and health care systems. Small amounts, however, do not diminish the importance that the system of unemployment benefits has in the prevention of social risks, particularly risks that come from the labour market.

The system of unemployment benefits provides an individual's income for the duration of temporary unemployment, i.e. provides social assistance during the period of long-term unemployment. Consequently, it is a key instrument of the welfare state in coping with labour market risks. Unemployment benefits gain special significance in conditions of crisis by acting as automatic stabilizers in mitigating the effects of economic shocks.

The effect of unemployment benefits as automatic stabilizers is evident from Table 5. In periods of GDP growth and lower unemployment, there is a noticeably smaller allocation of funds intended for the unemployed. On the other hand, during crisis, due to decreasing GDP and rising unemployment, there is an increase in unemployment benefits. Thus, in a period of expansion, activity is directed towards reduction, while recession is followed by stimulation of aggregate demand. The described pattern can be identified in the examples of the EU-15 countries, columns 1 and 2. Times of economic prosperity have been accompanied by a reduction, whereas the crisis has seen an increase in the allocation of funds for the unemployed.

In the pre-crisis period, the exceptions from the rule were Austria and Germany, which, despite a slight rise in unemployment, had not increased the share of unemployment benefits in the GDP. However, the explanation of this situation should primarily be sought in the institutional design of the unemployment benefits system, characteristic for CWR countries, 
Table 5. The change of social public expenditure for unemployment benefits in \% of GDP, EU-15

\begin{tabular}{lclclc}
\hline \multicolumn{1}{c}{ Country } & $\begin{array}{c}\text { \% change } \\
1995-2007\end{array}$ & Country & $\begin{array}{c}\text { \% change } \\
2007-2009\end{array}$ & Country & $\begin{array}{c}\text { \% change } \\
2009-2020^{*}\end{array}$ \\
\hline Sweden & -0.71 & France & 0.16 & Italy & -0.36 \\
\hline UK & -0.68 & Belgium & 0.17 & Germany & -0.26 \\
\hline Denmark & -0.66 & Portugal & 0.19 & France & -0.20 \\
\hline Netherlands & -0.60 & Austria & 0.22 & Finland & -0.18 \\
\hline Finland & -0.59 & Germany & 0.22 & Netherlands & -0.12 \\
\hline Ireland & -0.53 & Sweden & 0.24 & Austria & -0.11 \\
\hline Spain & -0.43 & Netherlands & 0.27 & Belgium & -0.04 \\
\hline Italy & -0.37 & Finland & 0.28 & Sweden & -0.03 \\
\hline Germany & -0.31 & Denmark & 0.37 & Greece & 0.02 \\
\hline France & -0.24 & Greece & 0.68 & Denmark & 0.04 \\
\hline Austria & -0.19 & UK & 0.70 & Portugal & 0.07 \\
\hline Belgium & -0.02 & Italy & 0.80 & UK & 0.15 \\
\hline Greece & 0.07 & Spain & 0.92 & Ireland & 0.19 \\
\hline Portugal & 0.17 & Ireland & 1.46 & Spain & 0.26 \\
\hline
\end{tabular}

Note: The forecast value for 2020 is taken from The 2012 Ageing Report. p. 274, Luxembourg is not included in the analysis.

Source: The authors' estimation based on OECD 2013 data.

rather than in the deviation from the general principle of their role as automatic stabilizers. Namely, in CWR countries, the mechanism of unemployment insurance is dominant with respect to the mechanism of unemployment assistance, which results in a lower sensitivity of the system of unemployment benefits to economic shocks. This occurs as a result of the system being based, to a great extent, on horizontal rather than vertical redistribution.

The period of crisis, as well as post-crisis projections, also support the arguments on the anti-crisis manifestations of the unemployment benefits system. In the period from 2007 to 2009 , the share of social public expenditure designated for unemployment benefits had increased in all the EU-15 countries. The largest increase in percentage compared to 2007 was in LWR and MWR countries, where the crisis had its most pronounced effects on the labour market. Moreover, the countries with the worst dynamics of number of unemployed persons during the crisis, LWR and MWR, are categorized as a group of countries with a prediction of the most intensive growth of public spending aimed at reducing the risk of the labour market in the next decade. On the other side, there are CWR and SDWR countries, for which it is realistic to expect that in the following years will slowly return to pre-crisis frameworks, in terms of GDP and unemployment trends. As a result of the restoration of pre-crisis relations, a gradual reduction of the share of public spending in the GDP aimed at the unemployed is also predicted. All this points towards the existence of a strong correlation between changes in expenditure designated for unemployment benefits and estimates on the movement of number of unemployed persons. 
Expectations that the crisis will leave more lasting consequences on the labour market of the EU-15 countries, in the form of persistently high unemployment rates in the post-crisis period, as well as on the extension of the average duration of unemployment, also make institutional reforms of the system of unemployment benefits inevitable. The direction of the reforms should be sought in the tendency to establish a balance between social security, incentives for the unemployed and fiscal costs (Stovicek, Turrini 2012).

The tendency to increase the efficiency of social public expenditure through the introduction and strengthening of corporate logic in welfare state programs will increasingly be expressed in the coming decades. The current architecture of the welfare state in the EU-15 renders the system of unemployment assistance the only productive element of social expenditure in the short term. A more flexible labour market, along with the simultaneous dominance of targeted and conditioned unemployment assistance, will be increasingly recognized by economic and social policy creators as the only remedy, from the perspective of sustainability of social expenditure, regarding the problems of poverty and social exclusion. In view of these arguments, institutional changes in the system of unemployment benefits as well as the repositioning of the welfare state in the direction of solving the problem of unemployment, seems certain to the extent that changes in the fluctuation of social public expenditure caused by the crisis are discernible today.

\section{Conclusions}

The findings indicate that the Great Recession of 2008, expressed, initially, through the decline in levels, and later, in the loss of the pre-crisis dynamics of production, has narrowed the real basis for redistribution and, hence, the manifestations of the welfare state. The manifestation of the crisis in the sharp increase in unemployment has expanded and deepened social problems by creating additional demand for welfare state programs. The status quo of social expenditure, derived from the inherent inertia and institutional rigidity of the welfare state, turns out to be unsustainable in conditions of a persistently high unemployment rate and low growth GDP rate.

In order to highlight the future trajectory of the EU-15 welfare state, the paper focused the changes in the pension system and the system of unemployment benefits. The analysis showed that the crisis was not a turning point for the reform of the pension systems, but that it affected their intensity and dynamics. Due to less institutional rigidity and an easier establishment of a social consensus, the reforms in the unemployment benefits systems became a point of reference for further institutional and redistributive redirection of the welfare state.

Given the crisis circumstances, the new orientation of the EU-15 welfare states could be recognized in the reforms for greater efficiency, firstly, in the context of input efficiency, and later, in the context of output efficiency, including re-levelling and re-institutionalization of the welfare state. CWR and SDWR countries lean towards the first scenario, while the second scenario seems more certain for LWR countries. The second scenario is already taking place in MWR countries. Examples of MWR countries - Greece and Portugal show that convergence or divergence along different lines, which are assumed by prevailing theories of welfare state 
typologies, is not only possible, but also already evident in the countries with less developed welfare states and external imposed welfare state reforms.

\section{Acknowledgements}

The first version of this paper was presented at the 10th International Conference Developments in Economic Theory and Policy (Bilbao, June 27-28, 2013). The paper is written under the auspices of the project 47010 supported by the Ministry of Education and Science, Republic of Serbia.

\section{References}

Adema, W.; Fron, P.; Ladaique, M. 2011. Is the European welfare state really more expensive? Indicators on social spending, 1980-2012; and a manual to the OECD Social Expenditure Database (SOCX), OECD Social, Employment and Migration Working Papers No. 124 . http://dx.doi.org/10.1787/5kg2d2d4pbf0-en

Ameco [online]. 2013 [cited 7 December 2013]. Available from Internet: http://ec.europa.eu/economy_finance/ameco/user/serie/SelectSerie.cfm

Armingeon, K. 2013. Breaking with the past? Why the global financial crisis led to austerity policies but not to modernization of the welfare state, in C. Pierson, F. G. Castles, I. K. Naumann (Eds.). The welfare state reader. $3^{\text {rd }}$ ed. Polity, 214-226.

Blot, C.; Cochard, M.; Creel, J.; Ducoudré, B.; Schweisguth, D.; Timbeau, X. 2014. Is there an alternative strategy for reducing public debt by 2032?, Panoeconomicus 61(1): 39-57. http://dx.doi.org/10.2298/PAN1401039B

Bonoli, G. 1997. Classifying welfare states: a two-dimension approach, Journal of Social Policy 26(3): 351-372. http://dx.doi.org/10.1017/S0047279497005059

Brauers, W. K. M.; Baležentis, A.; Baležentis, T. 2012. EUROPEAN Union member states preparing for EUROPE 2020. An application of the MULTIMOORA method, Technological and Economic Development of Economy 18(4): 567-587. http://dx.doi.org/10.3846/20294913.2012.734692

Castles, F. G. 2010. Black swans and elephants on the move: the impact of emergencies on the welfare state, Journal of European Social Policy 20(2): 91-101. http://dx.doi.org/10.1177/0958928711412224

Chung, H.; Thewissen, S. 2011. Falling back on old habits? A comparison of the social and unemployment crisis reactive policy strategies in Germany, the UK and Sweden, Social Policy \& Administration 45(4): 354-370. http://dx.doi.org/10.1111/j.1467-9515.2011.00779.x

Chung, H.; Van Oorschot, W. 2011. Institutions versus market forces: explaining the employment insecurity of European individuals during (the beginning of) the financial crisis, Journal of European Social Policy 21(4): 287-301. http://dx.doi.org/10.1177/0958928711412224

Clasen, J.; Clegg, D.; Kvist, J. 2012. European labour market policies in (the) crisis, European Trade Union Institute Working Paper No. 2011.02. http://dx.doi.org/10.2139/ssrn.2202724

De Beer, P. 2012. Earnings and income inequality in the EU during the crisis, International Labour Review 151(4): 313-331. http://dx.doi.org/10.1111/j.1564-913X.2012.00151.x

Esping-Andersen, G. 1990. The three worlds of welfare capitalism. Cambridge: Polity press. $492 \mathrm{p}$.

Esping-Andersen, G. 1996. After the golden age? Welfare state dilemmas in a global economy, in Welfare states in transition: National adaptations in global economies. Sage, 1-31.

Eurostat. 2014. Expenditure on pensions [online], [cited 1 February 2014]. Available from Internet: http://ec.europa.eu/eurostat/data/database 
$594 K$. Josifidis et al. The European welfare state regimes: questioning the typology during the crisis

Ferreiro, J.; Gómez, C. 2014. Implementing a voluntary wage policy: lessons from the Irish and Spanish wages policies before the crisis, Panoeconomicus 61(1): 107-127. http://dx.doi.org/10.2298/PAN1401107F

Ferrera, M. 1996. The 'Southern model' of welfare in social Europe, Journal of European social policy 6(1): 17-37. http://dx.doi.org/10.1177/095892879600600102

Hartmann-Hirsch, C. 2010. The state of the Luxembourg's welfare state: the effects of the crisis on a corporatist model shifting to a universalistic model, Working Paper No. 2010-44.

Hemerijck, A. C.; Knapen, B.; van Doorne, E. (Eds.). 2009. Aftershocks: economic crisis and institutional choice. Amsterdam University Press. 283 p. http://dx.doi.org/10.5117/9789089641922

Hermann, C. 2014. Structural adjustment and neoliberal convergence in labour markets and welfare: the impact of the crisis and austerity measures on European economic and social models, Competition \& Change 18(2): 111-130. http://dx.doi.org/10.1179/1024529414Z.00000000051

Josifidis, K.; Lošonc, A. 2014. Some thoughts on power: international context, Panoeconomicus 61(5): 597-615. http://dx.doi.org/10.2298/PAN1405597J

Josifidis, K.; Lošonc, A.; Supić, N. 2010. Neoliberalism: befall or respite? Panoeconomicus 57(1): 101-117. http://dx.doi.org/10.2298/PAN1001101J

Matsaganis, M. 2011. The welfare state and the crisis: the case of Greece, Journal of European Social Policy 21(5): 501-512. http://dx.doi.org/10.1177/0958928711418858

OECD. 2013. Social Expenditure Database (SOCX) [online], [cited 7 December 2013]. Available from Internet: http://www.oecd.org/social/expenditure.htm

Palier, B. (Ed.). 2010. A long goodbye to Bismarck? The politics of welfare reforms in continental Europe. Amsterdam University Press. 455 p. http://dx.doi.org/10.5117/9789089642349

Peinado, P.; Serrano, F. 2014. Fiscal crisis, social security reform and vulnerable population, Panoeconomicus 61(1): 129-143. http://dx.doi.org/10.2298/PAN1401129P

Pench, L.; Gudin De Vallerin, P.; Part, P.; Carone, G. 2012. The 2012 ageing report - economic and budgetary projections for the $27 \mathrm{EU}$ member states (2010-2060), The European Economy Series 1(2).

Sacchi, S.; Pancaldi, F.; Arisi, C. 2011. The economic crisis as a trigger of convergence? Short-time work in Italy, Germany and Austria, Social Policy \& Administration 45(4): 465-487. http://dx.doi.org/10.1111/j.1467-9515.2011.00785.x

Starke, P.; Kaasch, A.; Hooren, F. V. 2011. Explaining the variety of social policy responses to economic crisis: how parties and welfare state structures interact, TranState Working Papers No. 154 [online], [cited 7 December 2013]. Available from Internet: http://hdl.handle.net/10419/50561

Starke, P.; Kaasch, A.; Van Hooren, F. 2013. The welfare state as crisis manager: explaining the diversity of policy responses to economic crisis. Palgrave Macmillan. 236 p. http://dx.doi.org/10.1057/9781137314840

Stiller, S. 2010. Ideational leadership in German welfare state reform: how politicians and policy ideals transform resilient institutions. Amsterdam University Press. 253 p.

Stovicek, K.; Turrini, A. 2012. Benchmarking unemployment benefit systems, IZA Policy Papers No. 43 [online], [cited 7 December 2013]. Available from Internet: http://www.econstor.eu/handle/10419/91759

Theodoropoulou, S.; Watt, A. 2011. Withdrawal symptoms: an assessment of the austerity packages in Europe, European Trade Union Institute Working Paper No. 2011.02.

Verbič, M.; Spruk, R. 2014. Aging population and public pensions: theory and macroeconometric evidence, Panoeconomicus 61(3): 289-316.

http://dx.doi.org/10.2298/PAN1403289V

Vis, B.; Van Kersbergen, K.; Hylands, T. 2011. To what extent did the financial crisis intensify the pressure to reform the welfare state?, Social Policy \& Administration 45(4): 338-353.

http://dx.doi.org/10.1111/j.1467-9515.2011.00778.x 
Yerkes, M.; van der Veen, R. 2011. Crisis and welfare state change in the Netherlands, Social Policy \& Administration 45(4): 430-444. http://dx.doi.org/10.1111/j.1467-9515.2011.00783.x

Kosta JOSIFIDIS, Full Professor, University of Novi Sad, The Faculty of Economics Subotica, Serbia. Research interests: Macroeconomic theory and policy, International finance, Methodology of economics, Political economy of transition, Globalization and European economy.

John B. HALL, Full Professor, The Department of Economics, Portland State University, USA. Research interests: Evolutionary-Institutional Theory, Intersections between Philosophy and Economics, Central and East European Economies in Transition, Economics of Frontier Regions: with special interest on the bacia do rio Amazonas, South America's "third" giant.

Novica SUPIC, Assistant Professor, University of Novi Sad, The Faculty of Economics Subotica, Serbia. Research interests: Economics of the welfare state, Labour economics, Economic policy.

Emilija BEKER PUCAR, Assistant Professor, University of Novi Sad, The Faculty of Economics Subotica, Serbia. Research interests: Exchange rate regimes and monetary regimes. 